\title{
PERSEPSI DAN SIKAP MAHASISWA TERHADAP \\ RUBRIKGIZI DAN KESEHATAN DI MEDIA MASSA \\ (Studi pada mahasiswa FIK-UNJ dalam mempersepsi rubrik gizi dan \\ kesehatan di beberapa media massa)
}

\author{
Aan Wasan ${ }^{1}$ \\ ${ }^{1}$ Universitas Negeri Jakarta \\ aan.wasan@gmail.com
}

\begin{abstract}
Abstrak. Tujuan dari penelitian ini adalah untuk mengetahui persepsi dan sikap mahasiswa terhadap rubrik gizi dan kesehatan yang muat di media cetak. Metode yang digunakan adalah metode survei dengan disain penelitian deskriptif analisis. Penelitian dilakukan di Kampus Fakultas Ilmu Keolahragaan (FIK), Universitas Negeri. Pemilihan lokasi dilakukan secara sengaja (purposive) dengan pertimbangan,mahasiswa FIKmemiliki intensitas gerak yang tinggi. Meski demikian, intensitas dengan media massa yang menyajikan tulisan tentang gizi dan kesehatan, jarang mereka lakukan. Hasilnya menunjukkan bahwa seluruh mahasiswa yang berjenis kelamian perempuan yang menjadi responden dalam penelitian ini, memiliki persepsi baik terhadap rubrik gizi dan kesehatan yang disajikan media massa terbitan Jakarta. Sedangkan, mahasiswa yang berjenis kelamin laki-laki yang menjadi reponden, memiliki persepsi yang berbeda, dimana 50 persen berpersepsi baik dan 50 persen berpersepsi sedang terhadap rubrik gizi dan kesehatan ini. Sedangkan sikap mereka terhadap rubrik tersebut, dapat dijelaskan bahwa seluruh responden perempuan bersikap positif terhadap. Dengan demikian, 75 persen responden memiliki persepsi positif terhadap rubrik tersebut, sedangkan sisanya atau 25 persen berpersepsi sedang. Hasil penenilian ini juga menjelaskan tentang sikap responden, dimana 25 persen laki-laki memiliki sikap baik terhadap rubrik tersebut dan sisanya atau 75 persennya bersikap netral. Sementara itu, responden perempuan semuanya atau 100 persen memiliki sikap baik terhadap rubrik gizi dan kesehatan yang dimuat di media massa cetak.
\end{abstract}

Kata Kunci: Persepsi, Sikap, Rubrik kesehatan.

\section{PENDAHULUAN}

Untuk melihat tingkat kesehatan seseorang, Soejoeti menjelaskan dapat dilihat dari empat faktor yaitu lingkungan, perilaku, keturunan dan pelayanan kesehatan. Keempat faktor tersebut, lingkungan dan perilaku merupakan yang paling besar dalam mempengaruhi tingkat kesehatan masyarakat. Seiring perkembangan zaman, gaya hidup masyarakat,terutama pada remaja dan dewasa awal, mengalami perubahan yang sangat drastis yang cenderung tidak sehat. Aktivitas sehari-hari mereka relatif tinggi, disamping tuntutan pergaulan yang membuat kebiasaan-kebiasaan tidak sehat seperti sering mengkonsumsi fast food, tidak sempat sarapan pagi, merokok dan lebih banyak membuang 
waktu dalam ruangan sehingga tubuh mereka mengalami kekurangan gerak.

Gaya hidup tidak sehat menimbulkan akibat negatif yang kadang tidak disadari oleh remaja maupun orang dewasa. Masalah kesehatan yang sering terkait dengan gaya hidup adalah munculnya penyakit degeneratif. Penyakit degeneratif seperti hipertensi, penyakit jantung dan diabetes justru penderitanya dari tahun ke tahun kian meningkat jumlahnya. Berdasarkan data tahun 2001 menunjukkan penyakit jantung dan pembuluh darah merupakan penyebab kematian utama di dunia. Keadaan tersebut masih berlangsung sampai sekarang dan menjadi penyebab kematian utama pada usia produktif dengan perbedaan antara wanita dan pria semakin sempit. Penyakit yang berhubungan dengan kardiovaskuler bukan hanya masalah di negara maju, tetapi di negara berkembangpun menunjukkan penyakit ini menjadi penyebab 86 persen dari kasus kematian.

Kelompok pada masa remaja dan masa dewasa muda merupakan salah satu titik kritis dari sudut pandang kesehatan. Pada periode usia tersebut kerap meniru sikap dan perilaku yang berpengaruh terhadap kesehatan. Remaja lebih mudah terpengaruh kegiatankegiatan yang merusak kesehatan. Di sisi lain, mereka juga memiliki peluang untuk menambah pengalaman yangberpengaruh terhadap kesehatan yang positif seperti olahraga dan pola makan yang sehat.

Usia remaja merupakan usia peralihan ke arah yang lebih matang atau dewasa. Mereka biasanya berusaha untuk menemukan model untuk mengidentifikasi dirinya. Banyak media yang mempengaruhi perilaku remaja, salah satunya adalah media massa. Menurut Chan dan Sam, media massa merupakan sumber informasi yang penting bagi setiap orang. Banyaknya jumlah informasi yang diperoleh meningkatkan wawasan serta pola pikir yang lebih maju serta kreatif. Penelitian Supriyanti, menunjukkan hubungan yang signifikan antara kebutuhan menggunakan majalah dengan motif kognitif dan perilaku remaja dalam menggunakan majalah. Kemajuan zaman dan teknologi menjadikan media massa semakinberagam, baik media cetak maupun elektronik. Di Indonesia, perkembanganmedia massa telah menjadi industri sejak kebebasan pers dijamin denganUndang-Undang Nomor 40/1999 tentang Pers. Media cetak dan media elektroniksaling bersaing meningkatkan kualitasnya untuk menarik minat khalayak.

Sebagai saluran komunikasi massa yang memiliki keterlibatan tinggi, mediacetak memiliki keunggulan yaitu bentuknya ringkas, pembaca dapat mengatursendiri suasana, metode dan kecepatan pesan, pesan dapat diulang dan bisadisimpan sehingga bisa dibuka kembali saat diperlukan. Dengan kelebihantersebut media cetak dapat bertahan di tengah pertumbuhan media elektronikyang luar biasa. Bahkan dalam Konferensi ke-60 Asosiasi Suratkabar Dunia(WAN) dan sidang ke14 Forum Editor Dunia (WEF) di Cape Town tahun 2006 menemukan meningkatnya penetrasi internet justru membuat media cetak semakin dicari.

Media massa cetak dapat digunakan sebagai alat bantu menyampaikan pesan - pesan kesehatan. Media massa mampu mencapai banyak orang secara cepatsehingga pemanfaatannya dapat menyebarluaskan pesan kesehatan kepada semua orang (WHO 1992). Bentuk promosi kesehatan lewat media cetak yang mudah ditemukan adalah rubrik kesehatan yaitu tulisan-tulisan pada surat kabar, tabloid dan majalah yang membahas suatu topik tentang kesehatan atau hal-hal yang 
terkait dengannya. Berbeda dengan jurnal-jurnalkesehatan yang disampaikan dengan bahasa ilmiah, rubrik kesehatanpada media cetak disajikan dalam tulisan populer, sehingga lebih mudah dipahami oleh orang awam. Materi kesehatan yang dimuat membahasberagam topik mulai dari jenis - jenis penyakit, epidemi penyakit, cara pengobatan dan pencegahannya, teknologi di bidang kedokteran, program kesehatan sampai tips-tips ringkas untuk mempertahankan stamina tubuh.

Pada tabloid danmajalah, halaman tersebut dilengkapi dengan gambar sebagai ilustrasi untukmeningkatkan pemahaman pembaca. Isi rubrik dapat diasuh oleh redaksi media cetak atau oleh ahli-ahli di bidang kesehatan yang sudah terkenal dandiakui kemampuannya yang meningkatkan keyakinan pembaca. Pembaca rubrik kesehatan tidak mengenal batasan umur,kelompok ataupun jenis kelamin, artinya siapapun bisa menyukai rubrik tersebut. Hal ini terlihat dengan adanya rubrik gizi dan kesehatan yang tersebar meratapada surat kabar maupun pada media cetak yang sifatnya segmented seperti majalah dan tabloid. Rubrik kesehatan dapat ditemukan pada surat kabar nasional, misalnya pada harian Kompas, Republika dan Media Indonesia.

Rubrik serupa ditemukan lebih banyak dalam tabloid misalnya Nova, Nakita, Wanita Indonesia dan sebagainya. Dalam majalah misalnya Kartini, Femina, Nirmala dan Ayah Bunda serta yang lainnya. Ketika seseorang membaca surat kabar, tabloid atau majalah maka orangtersebut akan memberi penilaian terhadap apa yang dibacanya. Penilaian sangatdipengaruhi oleh nilai, harapan dan kebutuhan yang sifatnya sangat individualdan berbeda antarindividu. Kondisi demikian oleh Sumarwan disebut persepsi, yaitu cara pandang seseorang melihat realitas di luar dirinya atau lingkungan sekelilingnya yang ditentukan oleh stimulus yang diterimanya. Jika seseorang memiliki persepsi yang baik terhadap stimulus yang disajikan makaakan terbentuk kecenderungan bertindak atau sikap bahkan sampai perubahanperilaku. Penelitian Wahyuni terhadap konsumen rubrik kesehatanmenunjukkan pembaca memanfaatkan info kesehatan yang ada di tabloidkesehatan. Perilaku yang tampak antara lain pola makan teratur, istirahat danolahraga teratur dan kebiasaan menjaga lingkungan sehat.

Dengan demikian, peran media massa cukup tinggi dalam menyampaikan berbagai informasi. Mereka menerpa berbagai lapisan masyarakat, termasuk mahasiswa Fakultas Ilmu Keolahragaan (FIK), Universitas Negeri Jakarta (UNJ). Oleh karena itu, peneliti mencoba mendeskripsikan persepsi dan sikap mahasiswa FIK-UNJ terhadap rubrik kesehatan di majalah, koran dan tabloid yang mengulas tentang kesehatan.

UU nomor 23 Tahun 1992 tentang Kesehatan menjelaskan bahwa Kesehatan adalah keadaan sejahtera dari badan, jiwa, dan sosial yang memungkinkan setiap orang hidup secara produktif secara social dan ekonomi. Sedangkan WHO, kesehatan adalah kondisi dinamis meliputi kesehatan jasmani, rohani, sosial, dan tidak hanya terbebas dari penyakit, cacat, dan kelemahan. Sehat secara fisik artinya tidak memiliki gangguan apapunsecara klinis. Fungsi organ tubuhnya berfungsi secara baik, sehingga tidak merasaksakit.

Dengan demikian orang yang diyatakan sehata mental/psikis, yaitu orang yang sehat pikiran, emosional, maupun spiritual.Oleh karena itu, manakala ada orang yang merasa kondisi 
badannya serba tidak enak, tetapi hasil pemeriksaan dokter menunjukan tidak sakit, maka orangtersebut mengalami gangguan secara mental/psikis yang mempengaruhi keadaan fisiknya. Orang yang sehat secara mental adalah tidak autis, tidak stress, tidak mengalami gangguan jiwa akut, tidak mempunyai masalah yang berhubungandengan kejiwaan, misalnya kleptomania, psikopat, dan lain-lain. Penderita penyakithati juga merupakan contoh dari orang yang tidak sehat mentalnya, karena tidak adaseorang dokter bedah jantung sekalipun yang bisa menghilangkan penyakit ini dengan peralatan bedahnya.

Sementara orang yang dikategorikan sehat sosial adalah kemampuan seseorang untukberinteraksi dengan baik di lingkungannya. Orang yang tidak sehat sosial diantaranya adalah seorang Perempuan Seks Komersial (PSK), karena di tempat tinggalnya dia akan disisihkan. Sedangkan, orang dengan katagori sehat secara ekonomi adalah orang yang produktif. Produktifitasnyadapat menunjang kehidupan keluarganya.

Faktor-faktor yang Mempengaruhi Kesehatan. Saat ini gangguan kesehatan cenderung karena gizi salah (malnutrition). Gizi salah adalah keadaan patologis akibat kekurangan atau kelebihan secara alternatif maupun absolut satu atau lebih dari zat gizi. Ada empat bentuk Malnutrition (diktat Ilmu Gizi):

a) Undernutrition: kekurangan konsumsi pangan secara relatif maupun absolut untuk periode tertentu.

b) Specific Deficiency: kekurangan zat gizi tertentu, misalnya kekurangan vit A, Iodium, Fe, dan lain-lain. c) Over Nutrition: kelebihan konsumsi pangan untuk periode tertentu.

d) Imbalance: terjadi karena disproporsi zat gizi, misalnya: kolesterol terjadi karena tidak seimbangnya LDL (Low Density Lipoprotein), HDL (High Density Lipoprotein).

Malnutrisi adalah istilah umum untuk suatu kondisi medis yang disebabkan oleh pemberian atau cara makan yang tidak tepat atau tidak mencukupi.Istilah iniseringkali lebih dikaitkan dengan keadaan undernutrition (gizi kurang) yangdiakibatkan oleh konsumsi makanan yang kurang, penyerapan yang buruk, ataukehilangan zat gizi secara berlebihan. Namun demikian, sebenarnya istilahtersebut juga dapat mencakup keadaan overnutrition (gizi berlebih). Seseorang akan mengalami malnutrisi bila jumlah, jenis, atau kualitas yang memadai darizat gizi yang mencakup diet yang sehat tidak dikonsumsi untuk jangka waktutertentu yang cukup lama. Keadaan yang berlangsung lebih lama lagi dapatmenyebabkan terjadinya kelaparan.

Penyakit yang disebabkan karena gizi kurangini sangat berhubungan dengan terganggunya kesehatan yang dikenaldengan istilah penyakit kurang gizi. Hal ini merupakan masalah yang sangatkompleks, merupakan akibat dari suatu rangkaian proses masalah di masyarakat.Manutrisi akibat asupan zat gizi yang kurang untuk menjaga fungsi tubuh yangsehat seringkali dikaitkan dengan kemiskinan, terutama pada negara-negaraberkembang. Sebaliknya, malnutrisi akibat pola makan yang berlebih atau asupangizi yang tidak seimbang lebih sering diamati pada negara-negara maju, misalnyadikaitkan dengan angka obesitas yang meningkat. Obesitas adalah suatu keadaandi mana 
cadangan energi yang disimpan pada jaringan lemak sangat meningkat hingga ke mencapai tingkatan tertentu, yang terkait erat.

Sikap. Sikap merupakan konsep penting dalam literatur psikologi lebih dari satu abad, lebih dari 100 definisi dan 500 pengukuran sikap telah dikemukakan oleh para ahli. Namun dari berbagai definisi tersebut merujuk pada konsep evaluasi, sehingga dapat disimpulkan sikap adalah evaluasi konsep secara menyeluruh terhadap suatu objek oleh seseorang.

Sikap adalah ungkapan perasaan konsumen tentang suatu objek, apakah disukai atau tidak disukai, dan sikap juga bisa menggambarkan kepercayaan konsumen terhadap berbagai atribut dan menfaat dari objek tersebut. Sikap dianggap memiliki tiga unsur yaitu kognitif atau kepercayaan yang berhubungan dengan objek; afektif yang menunjukkan perasaan yang berhubungan dengan objek; dan konatif atau kecenderungan untuk bertindak atau keinginan untuk membeli.

Sikap belum merupakan suatu perbuatan, tetapi dari sikap seseorang dapat diramalkan perbuatannya dan sikap mengarahkan berperilaku secara langsung. Sikap negatif akan menimbulkan perilaku yang negatif misalnya menolak, menjauhi, meninggalkan bahkan sampai merusak. Sikap seseorang menentukan perilaku yang akan timbul dari orang tersebut terhadap suatu objek. Selain itu, sikap merupakan fungsi dari pengetahuan, pendapat, keyakinan dan penilaian seseorang terhadap objek (Pranadji 1988). Berbagai literatur psikologi penelitian-penelitian perilaku juga membuktikan bahwa sikap adalah peramal penting dari perilaku, kecenderungan berperilaku, dan faktor yang menjelaskan variasi perilaku.
Faktor yang dapat mempengaruhi kemudahan sikap menjadi tindakan nyata adalah tingkat kepentingan, jumlah frekuensi diaktifkan dan kekuatan asosiasi konsep. Melalui berbagai pengalaman, konsumen mendapatkan berbagai kepercayaan tentang produk, merek dan objek lain dalam lingkungan. Memiliki sikap yang secara umum baik atau buruk terhadap suatu produk tidak berarti bahwa konsumen tersebut akan selalu merealisasikan setiap kemungkinan sikap sehubungan dengan produk bersangkutan.

Persepsi. Sumarwan mendefinisikan persepsi konsumen sebagai cara pandang konsumen melihat realitas di luar dirinya atau dunia di sekelilingnya. Persepsi ditentukan oleh stimulus yang diterimanya dan bagaimana seseorang memahami stimulus tersebut sangat dipengaruhi oleh nilai-nilai, harapan dan kebutuhan yang sifatnya sangat individual. Kondisi tersebut sangat mungkin mengakibatkan dua orang mengambil arti yang berbeda terhadap stimulus yang sama. Rakhmat menjelaskan persepsi sebagai pengalaman tentang objek, peristiwa atau hubungan-hubungan yang diperoleh dengan menyimpulkan informasi dan menafsirkan pesan sehingga pengalaman akan mempengaruhi kecermatan persepsi.

Kotler dan Armstrong menyebutkan persepsi dipengaruhi duafaktor, yaitu faktor stimulus dan faktor individu. Faktor stimulus antara lain karakteristik fisik dari objek atau produk dan sumber informasi, sedangkan faktorindividu adalah karakteristik seseorang dan motivasi. Motivasi adalah dorongan bertindak untuk mencapai tujuan tertentu dan seseorang yang termotivasi siap untuk bertindak. Cara bertindak dipengaruhi persepsi dalam rangkaian proses memilih, mengatur dan menginterpretasikan informasi untuk 
membentuk gambaran. Hasil dari dorongan dan gerakan ini diwujudkan dalam bentukperilaku.

Menurut Sumarwan, persepsi melewati tahapan pemaparan,perhatian dan pemahaman. Tahap pemaparan adalah kegiatan penyampaian stimulus yang menyebabkan konsumen menyadari stimulus tersebut melalui pancaindra. Perhatian adalah kapasitas pengolahan yang dialokasikan konsumen terhadap stimulus yang masuk dan pemahaman adalah interpretasi terhadap makna stimulus. Stimulus diperhatikan karena mempunyai sifat-sifat yang menonjol, antara lain: gerakan, intensitas stimuli, kebaruan dan pengulangan. Tahapan persepsi termasuk dalam rangkaian pemrosesan informasi.

\section{METODE}

Metode yang digunakan dalam penelitian adalah metode survei dengan disain penelitian deskriptif analisis. Penelitian ini dilakukan di Fakultas Ilmu Keolahragaan (FIK), Universitas Negeri Jakarta (UNJ). Pemilihan mahasiswa FIK UNJ sebagai populasi dilakukan secara sengaja (purposive) denganpertimbangan mahasiswa FIK memiliki perhatian yang tinggi pada kesehatan. Oleh karena itu, peneliti ingin mengetahui penggunaan media massa sebagai sumber informasi tentang kesehatan yang digunakan oleh mahasiswa. Selain itu kampusFIK yang ada di tengah kota memiliki akses yang cukup mudah terhadap tersedianya media cetak.

Tabel 1. Skor rata-rata persepsi

\begin{tabular}{|c|l|c|c|c|}
\hline No & \multicolumn{1}{|c|}{$\begin{array}{c}\text { Pernyataan } \\
\text { Persepsi }\end{array}$} & Laki-laki & Perempuan & Total \\
\hline \multicolumn{3}{|c|}{ Materi } \\
\hline 1 & $\begin{array}{l}\text { Rubrik gizi dan } \\
\text { kesehatan } \\
\text { menarik untuk } \\
\text { dibaca }\end{array}$ & 3,8 & 4,3 & 4,5 \\
\hline 2 & $\begin{array}{l}\text { Topik-topik } \\
\text { yang disajikan } \\
\text { kurang aktual }\end{array}$ & 2,4 & 2,7 & 2,5 \\
\hline 3 & Informasi yang & 4,5 & 4,7 & 4,6 \\
\hline
\end{tabular}

\begin{tabular}{|c|c|c|c|c|}
\hline & $\begin{array}{l}\text { disajikan } \\
\text { dilengkapi data }\end{array}$ & & & \\
\hline 4 & $\begin{array}{l}\text { Informasi gizi } \\
\text { dan kesehatan } \\
\text { dilengkapi } \\
\text { dengan cara } \\
\text { mempraktekkan }\end{array}$ & 4,0 & 4,7 & 4,3 \\
\hline 5 & $\begin{array}{l}\text { Istilah-istilah } \\
\text { yang dipakai } \\
\text { dapat dipahami }\end{array}$ & 3,6 & 4,0 & 3,8 \\
\hline 6 & $\begin{array}{l}\text { Secara umum } \\
\text { isi rubrik gizi } \\
\text { dan kesehatan } \\
\text { mudah } \\
\text { dimengerti } \\
\end{array}$ & 3,8 & 4,0 & 3,9 \\
\hline \multicolumn{5}{|c|}{ PENYAJIAN } \\
\hline 7 & $\begin{array}{l}\text { Gaya bahasa } \\
\text { yang digunakan } \\
\text { cukup kreatif }\end{array}$ & 3,5 & 4,0 & 3,8 \\
\hline 8 & $\begin{array}{l}\text { Penataan } \\
\text { kalimat cukup } \\
\text { baik }\end{array}$ & 4,1 & 4,0 & 4,1 \\
\hline 9 & $\begin{array}{l}\text { Artikel pada } \\
\text { rubrik gizi dan } \\
\text { kesehatan } \\
\text { dilengkapi } \\
\text { gambar }\end{array}$ & 4,5 & 4,3 & 4,4 \\
\hline 10 & $\begin{array}{l}\text { Gambar } \\
\text { memperjelas isi } \\
\text { rubrik }\end{array}$ & 4,1 & 4,3 & 4,2 \\
\hline 11 & $\begin{array}{l}\text { Gambar tidak } \\
\text { sesuai dengan } \\
\text { isi rubrik }\end{array}$ & 2,4 & 2,0 & 2,2 \\
\hline 12 & $\begin{array}{l}\text { Gambar tidak } \\
\text { sesuai dengan } \\
\text { sosiobudaya } \\
\text { Indonesia } \\
\end{array}$ & 2,0 & 2,7 & 2,3 \\
\hline \multicolumn{5}{|c|}{ NARA SUMBER/PENULIS } \\
\hline 13 & $\begin{array}{l}\text { Penulis harus } \\
\text { seorang dan } \\
\text { kesehatan }\end{array}$ & 4,1 & 4,3 & 4,2 \\
\hline 14 & $\begin{array}{l}\text { Pengisi rubrik } \\
\text { mencantumkan } \\
\text { identitasnya }\end{array}$ & 4,1 & 4,0 & 4,1 \\
\hline 15 & $\begin{array}{l}\text { Penulis yang } \\
\text { terkenal } \\
\text { meningkatkan } \\
\text { kepercayaan } \\
\text { terhadap isi } \\
\text { rubrik }\end{array}$ & 4,4 & 4,0 & 4,2 \\
\hline
\end{tabular}

Keterangan:

Skor antara 1-5

Pernyataan positif $=$ nomor $1,3-10$, dan $13-15$

Pernyataan negatif $=$ nomor 2,11 dan 12

Skor rata-rata jawaban contoh cukup tinggi terlihat pada pernyataan "Rubrik gizi dan kesehatan cukup menarik untuk dibaca" (4.5). Pernyataan tersebut adalah positif, maka hal ini menunjukkan contoh setuju rubrik menarik untuk dibaca karena informasi sangat bermanfaat jika diterapkan dalam 
kehidupan sehari-hari disamping dapat menambah pengetahuan. Skor rata-rata jawaban juga cukup tinggi untuk pernyataan "Gambar memperjelas isi rubrik" (4.2). Contoh setuju bahwa dengan adanya gambar-gambar pada halaman kesehatan di media cetak dapat memperjelas materi yang disajikan sehingga meningkatkan pemahaman pembaca. Sebagai contoh pembaca akan lebih mudah menirukan gerakan senam jika disertai dengan gambar peragaan gerakannya dan informasi diet sehat yang menampilkan foto menu menarik akan menimbulkan keinginan untuk mencoba. Pernyataan negatif terkait gambar pada rubrik, yaitu "Gambar tidak sesuai dengan isi rubrik" dan "Gambar tidak sesuai dengan sosio-budaya Indonesia" masing-masing memiliki skor rata-rata 2,2 dan 2,3. Contoh tidak setuju pada kedua pernyataan tersebut, contoh menilai bahwa media cetak sudah mempertahankan kualitasnya dengan menyajikan gambar-gambar yang sesuai.

"Topik-topik rubrik gizi dan kesehatan kurang aktual" adalah pernyataan dengan skor rata-rata paling rendah yaitu sebesar 2,5. Karena pernyataan tersebut negatif maka contoh cenderung tidak setuju bahwa topik yang disajikan kurang aktual, artinya contoh merasa informasi gizi yang selama ini ditemukan di rubrik-rubrik serupa di media cetak sudah bersifat mengutamakan keterbaruan. Keinginan pembaca yang selalu ingin mendapat berita terbaru dan sangat cocok dengan karakteristik surat kabar yaitu publisitas, periodesitas, universalitas, aktualitas dan terdokumentasikan. Di samping materi, bahasa juga mempengaruhi keinginan pembaca untuk menyimpan informasi.

Skor rata-rata jawaban contoh tinggi untuk sebagian besar pernyataan persepsi terhadap penyajian yang mencakup aspek kebahasaan dan ilustrasi. Hal ini menunjukkan gaya bahasa, kalimat dan gambar yang ada pada rubrik dinilai contoh sudah baik. Skor jawaban cukup tinggi ditunjukkan oleh pernyataan "Penulis harus mencantumkan identitasnya" (4.1). Contoh setuju dengan pernyataan tersebut diduga karena pembaca mengganggap bahwa dengan mengetahui identitas pengisi rubrik dapat mempengaruhi keyakinan pembaca. Penulis yang dikenal dan ahli di bidangnya dapat meningkatkan kepercayaan pembaca terhadap informasi.

Menurut Ardiyanto dan Erdinaya kemampuan sumber beritadalam memaparkan materinya adalah salah satu faktor yang menentukan keberhasilan informasi untuk diadopsi oleh pembaca. Skor rata-rata contoh perempuan $(3,9)$ sedikit lebih besar daripada contoh lakilaki (3.7) pada pernyataan "Penulis yang terkenal meningkatkan kepercayaan terhadap isi rubrik" dengan skor rata-rata keseluruhan adalah 4,2. Hal tersebut diduga karena contoh perempuan memiliki tingkat kepentingan lebih tinggi untuk mengetahui siapa narasumber informasi. Walaupun kedua kelompok memperlihatkan perbedaan skor rata-rata namun secara umum contoh setuju pada pernyataan tersebut.

Jawaban setuju atau tidak setuju terhadap pernyataan persepsi memperlihatkan baik tidaknya persepsi contoh terhadap rubrik gizi dan kesehatan. Secara keseluruhan skor persepsi yang berkategori baik yang memiliki skor $>55$ ada $75 \%$ dari seluruh responden. Pada tabel di bawah ini dapat dilihat bahwa $100 \%$ atau seluruh responden perempuan memiliki persepsi baik. Sedangkan responden laki-laki hanya $50 \%$. Sedangkan sisanya laki-laki $(50 \%)$ memiliki persepsi pada tingkat sedang. 
Tabel 2. Sebaran berdasarkan tingkat persepsi terhadap rubrik gizi dan kesehatan

\begin{tabular}{|c|c|c|c|}
\hline Tingkat Persepsi & Laki-laki & Perempuan & Total \\
\hline Baik $(>55)$ & $50 \%$ & $100 \%$ & $75 \%$ \\
\hline Sedang $(35-55)$ & $50 \%$ & - & $25 \%$ \\
\hline Kurang $(<35)$ & - & - & - \\
\hline
\end{tabular}

Sikap Mahasiswa terhadap Rubrik Gizi dan Kesehatan. Sikap adalah evaluasi konsep secara menyeluruh terhadap suatu objek oleh seseorang. Seperti pernyataan persepsi, pernyataan sikap hanya diisi oleh contoh yang memiliki kebiasaan membaca rubrik gizi dan kesehatan. Dalam tabel menunjukkan contoh menjawab setuju untuk sebagian besar pernyataan dengan rentang jawaban contoh antara 2 (tidak setuju) hingga 5 (sangat setuju) pada pernyataan positif dan rentang jawaban antara 2 (setuju) hingga 5 (sangat tidak setuju) untuk pernyataan negatif. Skor sikap paling tinggi terdapat pada pernyataan "Rubrik gizi dan kesehatan memberi manfaat" (4.44). Karena pernyataan tersebut positif maka contoh setuju bahwa dengan membaca rubrik gizi dan kesehatan dapat menambah pengetahuan dan akan memperoleh manfaat informasi yang sangat beragam tersebut diterapkan. Contoh juga setuju bahwa "Informasi kesehatan sesuai dengan kebutuhan" (4.1).

Informasi kesehatan yang cocok untuk rentang usia dewasa muda adalah seputar diet dan perawatan tubuh, karena pada periode ini dewasa muda dan remaja sedang menentukan model identifikasi berperilaku dan sangat tertarik untuk memperoleh bentuk tubuh ideal.
Tabel 3. Skor Rata-rata Sikap

\begin{tabular}{|c|c|c|c|c|}
\hline No & $\begin{array}{l}\text { Penyataan } \\
\text { Sikap }\end{array}$ & $\begin{array}{c}\text { Laki- } \\
\text { laki }\end{array}$ & Perempuan & Total \\
\hline 1 & $\begin{array}{l}\text { Rubrik gizi dan } \\
\text { kesehatan } \\
\text { memberi } \\
\text { manfaat pada } \\
\text { diri saya }\end{array}$ & 4,5 & 4,7 & 4,6 \\
\hline 2 & $\begin{array}{l}\text { Informasi pada } \\
\text { rubrik gizi dan } \\
\text { kesehatan } \\
\text { sesuai dengan } \\
\text { kebutuhan saya }\end{array}$ & 3,9 & 4,3 & 4,1 \\
\hline 3 & $\begin{array}{l}\text { Menurut saya } \\
\text { frekuensi } \\
\text { pemuatan } \\
\text { informasi gizi } \\
\text { dan kesehatan } \\
\text { di media cetak } \\
\text { masih kurang }\end{array}$ & 3,4 & 3,0 & 3,2 \\
\hline 4 & $\begin{array}{l}\text { Kemudahan } \\
\text { cara penerapan } \\
\text { informasi gizi } \\
\text { dan kesehatan } \\
\text { meningkatkan } \\
\text { minat saya } \\
\text { untuk } \\
\text { membaca lebih } \\
\text { lanjut }\end{array}$ & 4,3 & 4,7 & 4,5 \\
\hline 5 & $\begin{array}{l}\text { Saya tertarik } \\
\text { untuk mencoba } \\
\text { tips-tips } \\
\text { kesehatan }\end{array}$ & 4,4 & 4,7 & 4,5 \\
\hline 6 & $\begin{array}{l}\text { Kalimat- } \\
\text { kalimat pada } \\
\text { rubrik gizi dan } \\
\text { kesehatan } \\
\text { membosankan }\end{array}$ & 2,9 & 2,7 & 2,8 \\
\hline 7 & $\begin{array}{l}\text { Saya tetap } \\
\text { membaca } \\
\text { rubrik gizi dan } \\
\text { kesehatan } \\
\text { walaupun } \\
\text { banyak } \\
\text { memakai } \\
\text { istilah } \\
\text { kedokteran } \\
\end{array}$ & 3,4 & 4,7 & 4,0 \\
\hline 8 & $\begin{array}{l}\text { Menurut saya } \\
\text { isi rubrik gizi } \\
\text { dan kesehatan } \\
\text { sangat lemah } \\
\text { untuk diyakini } \\
\text { kebenarannya }\end{array}$ & 1,9 & 3,3 & 2,6 \\
\hline 9 & $\begin{array}{l}\text { Saya selalu } \\
\text { membaca } \\
\text { rubrik gizi dan } \\
\text { kesehatan yang } \\
\text { saya temukan } \\
\text { pada koran dan } \\
\text { majalah }\end{array}$ & 3,1 & 4,7 & 3,9 \\
\hline 10 & $\begin{array}{lr}\text { Saya } & \text { lebih } \\
\text { tertarik } & \text { pada } \\
\text { rubrik } & \text { lain } \\
\text { daripada } & \text { rubrik } \\
\text { gizi } & \text { dan } \\
\text { kesehatan } & \\
\end{array}$ & 3,0 & 2,3 & 2,7 \\
\hline
\end{tabular}

Keterangan

Skor antara 1-5

Pernyataan positif $=$ nomor $1-2,4-5,7$ dan 9

Pernyataan negatif $=$ nomor $3,6,8$ dan 10 
Pernyataan "Saya tertarik untuk mencoba tips-tips kesehatan" menunjukkan rata-rata cukup tinggi yaitu 4.5. Kecenderungan contoh untuk setuju pada pernyataan tersebut menunjukkan pada dasarnya contoh bersikap positif pada informasi yang dimuat pada rubrik gizi dan kesehatan. Hal ini diperkuat dengan skor rata-rata jawaban contoh yang juga cukup tinggi untuk pernyataan "Kemudahan cara penerapan informasi meningkatkan minat saya untuk membaca lebih lanjut" (4.5).

Tips yang praktis dan mudah diterapkan meningkatkan keinginan pembaca untuk lebih dari sekedar membaca rubrik dan diharapkan berpengaruh pada perilaku sehat seharihari untuk memperoleh status kesehatan yang baik. Skor 2.6 terdapat pada pernyataan "Frekuensi pemuatan informasi gizi dan kesehatan di media cetak masih kurang" dan karena pernyataan tersebut negatif maka contoh setuju pada pernyataan tersebut. Menurut contoh rubrik gizi dan kesehatan pada surat kabar, majalah maupun tabloid masih sedikit sehingga tidak mudah ditemukan. Hal ini mendukung alasan contoh yang tidak pernah membaca rubrik gizi dan kesehatan yaitu tidak pernah menemukan rubrik yang dimaksud pada media cetak yang dibaca. "Kalimat-kalimat pada rubrik gizi dan kesehatan membosankan" adalah pernyataan negatif dengan skor rata-rata keseluruhan 2,8 .

Terdapat perbedaan skor cukup besar antara contoh laki-laki (2.84) dan perempuan (3.40) dimana contoh lakilaki cenderung setuju sedangkan contoh perempuan cenderung tidak setuju. Namun jika dikaitkan dengan pernyataan "Saya tetap membaca walaupun banyak menggunakan istilah kedokteran" yang menunjukkan skor rata-rata cukup tinggi (3.68) dapat disimpulkan contoh menuntaskan membaca sampai akhir walaupun membosankan. Wahyuni menjelaskan bahasa yang baik ialah sesuai EYD, efektif, efisien, memperhatikan pilihan kata terutama istilah khusus di bidang kesehatan. Semakin menarik topik dan penyajian bahasanya, semakin tinggi keinginan pembaca untuk memanfaatkan informasi atau menyimpannya dengan asumsi akan digunakan di waktu tertentu. Skor ratarata cukup tinggi terdapat pada pernyataan negatif "Isi rubrik gizi dan kesehatan sangat lemah untuk diyakini kebenarannya" (3.53).

Skor cukup besar menunjukkan contoh cenderung tidak setuju bahwa isi rubrik tidak dapat dipercayai oleh pembaca, dengan kata lain contoh meyakini kebenaran informasi yang dibacanya. Media sangat tergantung pada isi pesan, digunakan untuk apa, dalam bentuk apa, siapa yang menyampaikan, siapa penerimanya dan sebagainya. Agar pesan dapat dipercaya dan akurat, maka harus didukung oleh data apalagi jika dilengkapi dengan data kualitatif. Perbedaan skor rata-rata terdapat juga sikap antara contoh laki-laki dan perempuan terdapat pada pernyataan "Saya lebih tertarik pada rubrik lain daripada rubrik gizi dan kesehatan". Skor rata-rata contoh perempuan (3.4)lebih besar daripada skor rata-rata contoh laki-laki (3.7), artinya contoh perempuan cenderung tidak setuju pada pernyataan tersebut. Contoh laki-laki lebih tertarik pada rubrik selain gizi dan kesehatan, hal ini memperkuat hasil sebelumnya bahwa contoh perempuan lebih menyukai rubrik gizi dan kesehatan. Jawaban setuju atau tidak setuju terhadap pertanyaan sikap memperlihatkan baik tidaknya sikap contoh terhadap rubrik gizi dan kesehatan. Secara keseluruhan skor sikap berkisar antara 23-36yang menunjukkan sikap netral ada 37,5\% dari keseleuruhan 
responden. Sedangkan sisanya ada $6,2,5 \%$ bersikap positif terhadap rubrik tersebut. Tabel di bawah ini menunjukkan sebagian besar contoh baik laki-laki $(25 \%)$ dan perempuan $(100 \%)$ atau semua responden perempuan memiliki sikap positif.

Tabel 4. Sikap Mahasiswa terhadap Rubrik Gizi dan Kesehatan

\begin{tabular}{|l|c|c|c|}
\hline \multicolumn{1}{|c|}{$\begin{array}{c}\text { Tingkat } \\
\text { Sikap }\end{array}$} & Laki-laki & Perempuan & Total \\
\hline Positif (>36) & $25 \%$ & $100 \%$ & $62,5 \%$ \\
\hline $\begin{array}{l}\text { Netral (23- } \\
36)\end{array}$ & $75 \%$ & - & $37,5 \%$ \\
\hline $\begin{array}{l}\text { Negatif } \\
(<23)\end{array}$ & - & - & - \\
\hline
\end{tabular}

Laki-laki yang memiliki sikap netral menunjukkan proporsi cukup besar $(75 \%)$, sedangkan pada perempuan sikap positif (100\%) dari seluruh contoh. Dengan tidak satu pun laki-laki atau perempuan yang memiliki sikap negatif terhadap rubrik gizi dan kesehatan, hal ini menunjukkan bahwa semua responden mempunyai sikap yang lebih baik terhadap rubrik gizi dan kesehatan daripada contoh laki-laki.

Hasil uji statistik menyatakan bahwa terdapat perbedaan signifikan antara sikap laki-laki dan perempuan $(\mathrm{p}<0.05)$. Sikap seseorang menentukan perilaku yang akan timbul dari orang tersebut terhadap objek. Memiliki sikap yang secara umum baik atau buruk terhadap sesuatu tidak berarti bahwa konsumen tersebut akan selalu merealisasikan setiap kemungkinan sikap sehubungan dengan objek bersangkutan (Peter \& Olson 1999). Sikap negatif akan menimbulkan perilaku yang negatif misalnya menolak, menjauhi, meninggalkan bahkan sampai merusak (Pranadji 1988). Sikap yang negatif terhadap media cetak tidak membuat pembaca sampai membuang atau merusak medianya karena pada dasarnya contoh setuju bahwa informasi tersebut bermanfaat.
Sikap negatif yang ditunjukkan oleh contoh laki-laki menunjukkan contoh laki-laki belum berminat untuk menerapkan informasi tersebut dalam kehidupan sehari-hari dan informasi baru mencapai tahap menambah pengetahuan saja. Sebaliknya sikap positif menunjukkan kecenderungan contoh untuk mengambil tindakan setelah membaca, misalnya mempraktekkan informasi atau sekedar berbagi informasi dengan orang lain. Sikap positif contoh perempuan diduga berkaitan dengan karakteristik perempuan yang lebih tertarik pada perawatan tubuh dan topiktopik seperti ini merupakan sebagian besar isi dari rubrik gizi dan kesehatan di media cetak.

\section{DAFTAR PUSTAKA}

Ardianto A, Erdinaya LK. Komunikasi Massa Suatu Pengantar. Bandung: Penerbit Remaja Rosdakarya, 2004.

Cangara H. Pengantar Ilmu Komunikasi. Jakarta: PT. Raja Grafindo, 1998.

Chan SM, Sam TT. Analisis SWOT Kebijakan Pendidikan Era Otonomi Daerah. Jakarta: PT Raja Grafindo Persada, 2006.

De Fleur ML, Ball-Rokeach S. Theories of Mass Comunication, 4 ed. New York: Longman Inc, 1982.

Effendy OU. Hubungan Masyarakat: Suatu Studi Komunikologis. Bandung: Penerbit Remaja Rosdakarya, 2002.

Engel JF, Blackwell RD, Miniard PW. Perilaku Konsumen (6 ed). Jilid 1. Fx Budiyanto, penerjemah. Jakarta: Binarupa Aksara, 1994.

Khomsan A. Pangan dan Gizi untuk Kesehatan. Jakarta: PT Raja Grafindo Persada, 2002.

Kotler P, Armstrong G. Prinsip-Prinsip Pemasaran. Jilid 1. (D. Sihombing). Jakarta: Penerbit Erlangga, 2001. 
McKenzie JF, Pinger RR, Kotecki JE. Kesehatan Masyarakat: Suatu Pengantar. Utami A, Hippy N dan Nurlinawati I, penerjemah). Jakarta: EGC Penerbit Buku Kedokteran, 2006.

McQuail D. Teori Komunikasi Massa, Edisi Ke-2. Dharma A dan Ram A, penerjemah. Jakarta: Penerbit Erlangga, 1987.

Mostafa MM. Gender differences in Egyptian consumers' green purchase behaviour: the effects of environmental knowledge, concern and attitude. International Journal of Consumer Studies 31 (2007): 220-229.

Mowen JC, Minor M. Perilaku Konsumen. Jilid 1. Salim L, penerjemah. Jakarta: Penerbit Erlangga, 2002.

Notoatmodjo. Promosi Kesehatan dan Ilmu Perilaku. Penerbit Rineka Cipta, Jakarta, 2007.

Peter JP, Olson JC. Perilaku Konsumen dan Strategi Pemasaran. Edisi ke-4. Sihombing D, penerjemah. Jakarta: Penerbit Erlangga, 1999.

Pranadji. Pendidikan Gizi (Proses Belajar Mengajar) [diktat]. Bogor: Jurusan Gizi Masyarakat dan Sumber Daya Keluarga, Fakultas Pertanian.Institut Pertanian Bogor, 1988.

Rakhmat J. Psikologi Komunikasi. Bandung: Penerbit Remaja Rosdakarya, 2005.

Sani A. 2007. Penatalaksanaan Penyakit Jantung dan Stroke Secara baik dan Benar. Di dalam: Seminar Hipertensi, Hiperkolesterol, Hiperglikemia. Bogor, 1 Desember 2007. Program Studi Gizi Masyarakat dan Sumberdaya Keluarga, Institut Pertanian Bogor, 2007. Hlm 1-22.
Schiffman LG, Kanuk LL. Consumer Behaviour (8th ed). New Jersey: Pearson Prentice Hall, 2004.

Singarimbun dan Effendy. Metode Penelitian Survei. LP3ES, Jakarta, 1989.

Soejoeti SZ. Konsep Sehat, Sakit dan Penyakit dalam Konteks Sosial Budaya [terhubung berkala] http://www.kalbe.co.id, 2005

Sumarwan U. Perilaku Konsumen Teori dan Penerapannya dalam Pemasaran. Bogor: Ghalia Indonesia, 2004.

Wahyuni ES. Faktor-faktor yang berhubungan dengan perilaku pembaca dalam memperoleh informasi gaya hidup sehat (Studi kasus pembaca Tabloid Senior di Kecamatan Bogor Utara) [tesis]. Bogor: Program Pascasarjana Institut Pertanian Bogor, 2007.

WHO. Pendidikan Kesehatan: Pedoman Pelayanan Kesehatan Dasar. Tjitarsa IB, penerjemah. Bali: Penerbit Universitas Udayana, 1992. 